Journal homepage: http://www.interscience.org.uk

DOI: $10.18535 / \mathrm{ijahm/v7i4.07}$

Impact factor: 4.415

\title{
Ayurvedic And Modern Therapeutic Aspect Of Lavang Tail
}

\author{
${ }^{1}$ Dr. Salve Nilesh , ${ }^{2}$ Dr. Gangasagre N. S. , ${ }^{3}$ Dr. Pandhare Ravindra , ${ }^{4}$ Dr. MirajkarShital , \\ ${ }^{5}$ Dr. PhadkeSukrut \\ ${ }^{1}$ PG Scholar, Agadtantra Dept. GAC Osmanabad \\ ${ }^{2}$ Prof. \& Head of Department AgadtantraDept, GAC Osmanabad. \\ ${ }^{3}$ PG Scholar, Agadtantra Dept. GAC Osmanabad Assist Prof, Agadtantra Dept. GAC Osmanabad. \\ ${ }^{4}$ Assist. Prof., Agadtantra Dept. GAC Osmanabad. \\ ${ }^{5}$ PG Scholar, RasaShastra Dept. GAC Osmanabad.
}

\section{Corresponding Address-}

\section{Dr. Nilesh Salve}

PG Scholar, Agadtantra Dept. GAC Osmanabad. Maharashtra -413501

\begin{abstract}
-
Lavang(Syzygiumaromaticum) has antimicrobial, anti-inflammatory, anti-oxidant properties aswell as anticarcinogenic,anti-mutagenic properties. According to Ayurveda lavang has tiktaand katu rasa and sheet virya. Due tokatu rasa it acts as kaphashamaka andpitta hara, due to sheetaveerya. Therefore, lepa (local application of paste) of lavang is applied on forehead in pratishyayjanyashirshoola (sinusitis induced headache). It acts as uttejak (aphrodisiac) in dhvajbhang (erectile dysfunction) due to its tikshnaguna. It also acts as krumighna(wormicidal) therefore it is used in dantshool (dental carries). In vyadhis (diseases) like amvaatkatishoolgrudhrasi local application of lavang tail reduces the pain. Due to its tikshnaguna, the salivary secretion increases and also the fibroblastic activity of mucus membrane ceases. Hence it can be used in oro-dental conditions like sub mucus fibrosis as it increases fibroclastic activity of cell. Clove hastwo major chemical components, Euginol and Beta Caryophyllene, which constitute 78\% and 13\% respectively. Both have cytotoxic property towards human fibroblasts and endothelial cells. Clove also has been effective in inhibition of cell proliferation in carcinogenesis.Euginol also helps in inhibition of fungal growth. The leaves of clove containbetulinic acid, which also has cytotoxic property in certain cancers like breast cancer. This study aims at the therapeutic use of clove indicated in Ayurvedic literature and research studies conducted on the same. Comprehension of such literature is need of an hour for further clinical trials.
\end{abstract}

Keywords - Lavang tail, Chemical constituents, Therapeutic uses

\section{Introduction -}

According kalidasa(Ancient Ayurveda Acharya),lavangpushpa (clove flower) are firstly found in dvipantara i.e. iseland ${ }^{[1]}$. In Charak and Sushrutsamhita the therapeutic use of lavang indicated with tambulsevana(betal leaf chewing). It is kaphachhedak and pitta shamak. Thats why it is used in Indian spices.Lavanghas great antioxidant property. Clove actually means symbol of dignity. It is unopened flower bud growing on a tree belonging to Myrtaceae family. It is native of Indonesia but now days cultivated in several part of world. It contains phenolic compounds such as euginol, euginol acetate, gallic acid which are having great pharmaceutical and cosmetic uses. Clove is beneficial home remedy for several diseases. It possess antioxidant, anti-fungal, anti-viral, anti-microbial, anti-diabetic, anti-inflammatory, anesthetic, pain reliving, insect repellent properties.

1.1Aims -Ayurvedic and modern therapeutical aspects of lavang tail 
${ }^{1}$ Dr. Salve Nilesh, International Journal of Ayurvedic \& Herbal Medicine 7(4) July.-Aug.2017 (2685-2692)

\subsection{Objectives -}

1. To collect and analyze the literature review of lavanga

2. To collect and analyze chemical component of lavangand its effect on body

3. To study the therapeutic uses of lavang.

\subsection{Methodology}

To fulfill the aims and objectives of the study this work has been carried out in the following phase wise manner.
1. Conceptual study
2. Comparative study
3. Discussion
4. Conclusion and summary

\subsection{Clove synonyms -}

Sanskrit names-devkusuma, devapuspa, lavanga, sriprasun, chandanpushpak, vaareej,

English names - clove, clovos, caryophyllus, carophyllus

Botanical names - Eugenia caryophyllus, Syzygiumaromaticum.

Family -Myrtaceae

Hindi -lavang, laung

Marathi -lavang

Malayalam -grampu, karayampu

Kannada -krambu, daevakusuma, lavanga

Tamil -kirampu, kiraambu, grambu

Bengali -lavanga

Gujrati -lavang

Oriya-labanga

Urdu-laung

\subsection{Phylotaxy of Clove tree-}

Height - 30-40 feet in hight,

Leaves-Oval shaped green leaves of 3-6 inch in length

Flowers - Aromatic, Lavender colored

Fruits- Clove like shape, Named as mother clove

Clove buds- In dry form used as spices

\subsection{Collection-}

After 7-8 years of age there is formation of buds.

Developing clove buds are collected before they get full grown.

\subsection{Time of collection-}

When clove buds turn pinkish from green color.

A tree yields $2.5-4.5 \mathrm{~kg}$ clove at one time.

These immature clove buds then dried for 4-5 days in sunlight. And then used.

2.5 Nutritive value of clove ${ }^{[2]}$.

\begin{tabular}{|l|l|}
\hline Content & Nutrient value per 100gm \\
\hline Protein & $5.98 \mathrm{gm}$ \\
\hline Fat & $20.07 \mathrm{gm}$ \\
\hline Carbohydrate & $61.21 \mathrm{gm}$ \\
\hline
\end{tabular}


${ }^{1}$ Dr. Salve Nilesh, International Journal of Ayurvedic \& Herbal Medicine 7(4) July.-Aug.2017 (2685-2692)

\begin{tabular}{|l|l|}
\hline Energy & $323 \mathrm{kcal}$ \\
\hline Calcium & $646 \mathrm{mg}$ \\
\hline Phosphrous & $105 \mathrm{mg}$ \\
\hline Iron & $8.64 \mathrm{mg}$ \\
\hline Carotin & $84 \mathrm{mcg}$ \\
\hline Thiamine & $0.115 \mathrm{mg}$ \\
\hline Riboflavin & $0.267 \mathrm{mg}$ \\
\hline Niacin & $1.458 \mathrm{mg}$ \\
\hline Folates & $93 \mathrm{mcg}$ \\
\hline Copper & $0.347 \mathrm{mg}$ \\
\hline Magnesium & $264 \mathrm{mg}$ \\
\hline Manganese & $30.033 \mathrm{mg}$ \\
\hline Zinc & $1.09 \mathrm{mcg}$ \\
\hline Potassium & $1102 \mathrm{mg}$ \\
\hline Sodium & $243 \mathrm{mg}$ \\
\hline Vit A & $530 \mathrm{IU}$ \\
\hline Vit C & $80.8 \mathrm{mg}$ \\
\hline Vit E & $8.52 \mathrm{mg}$ \\
\hline Vit K & $141.8 \mathrm{mcg}$ \\
\hline
\end{tabular}

\subsection{Ayurvedic properties-}

Guna-snigdha, laghu

Rasa-tikta, katu

Vipak-katu

Veerya- sheet

Karma- dosh karma- due to tiktakatu rasa it is kaphashamak, due to its sheet veerya it is pitta shamak

3.2 Local action- Due to its tikshnaguna it is raktotkleshak(blood agrevator), uttejak(stimulant), krimighna(wormicidal)

\subsection{Internal action ${ }^{[3]}$ -}

\begin{tabular}{|l|l|l|l|}
\hline No & System & Guna & Karma \\
\hline 1. & Digestive & Katu, tikta rasa & Deepanpachan(appetizer), ruche vardhan(taste improver) \\
\hline & & Teekshaguna & Salivary secretion increases \\
\hline & & Snigdhaguna & Vatanulomak(carminative), shoolprashamak(analgesic) \\
\hline 2. & Circulatory & Tikta rasa & Raktadushtinashan(blood purifier) \\
\hline 3. & Respiratory & Katutikta rasa & Shleshmaputihar(mucolytic) \\
\hline 4. & Reproductive & Prabhav & Vajikaran (aphrodiasic). \\
\hline & & Katuvipak & Stanyajanan(lactogenic), \\
\hline 5. & Excretory & Prabhav & Mutrajanan (diuretic) \\
\hline 6. & Fever & Tikta rasa & Jwaraghna (antipyretic) \\
\hline
\end{tabular}


${ }^{1}$ Dr. Salve Nilesh, International Journal of Ayurvedic \& Herbal Medicine 7(4) July.-Aug.2017 (2685-2692)

\subsection{Therapeutic uses by Samhitas ${ }^{[4]}$ \#}

1. Shirshooljanyapratishyay(sinusitis induced headache)- Local application of lepa on forehead

2. Mukharoga,kantharoga (orodental disorder) - Chewing of clove

3. Aamvata(Rheumatoid Arthritis), katishool(Backache), grudhrasi (Sciatica), vaatvikar(Neurological Disorder)- Clove oil massage for local pain relief

4. Dantshool(Toothache)- Cotton plug of lavang tail

5. Dhvajbhang (Erectile Dysfuction) - Oil application on penis for aphrodasiac action

6. Aamplapitta(Hyperacidity) - Aampachan , Agni deepan(appetizer) Pitta vidah shanti (Reducing Burning Sensation), Shoshan of drava pitta.

7. Kaas, shwas, hikka(respiratory disorder)

8. Jwara(Fever) -LavangodakinJwara. Aruchi(Anorexia), Agnimandya(Loss of appetite), Ajeerna (Dyspepsia),Chhardi(Vomitting),Trushna(Excessive thirst), yakrutvikara (liver disorder)

9. Firang, upadansha(soft chancre) - raktadushtinaash(purification of vitiated rakta)

10. Lavangambu - In visuchika, pipasa(cholera oinducetrushna) ${ }^{[5]}$

11. Koshnajalapishtvalepa(local application of paste)- In vaatvikara (Neurological Disorder) for pain relief.

\subsection{Chemical compostion of clove-}

Clove contains volatile and non volatileconstituents ${ }^{[6]}$

\subsection{Volatile constituents-\#}

\begin{tabular}{|l|l|}
\hline Clove part & Constituent \\
\hline Bud oil & $\begin{array}{l}\text { Essential oil - 15-20\% } \\
\text { Euginol - 70-85\% } \\
\text { Euginol acetate- 15\% } \\
\text { Beta caryophyllene - 5-12\% } \\
\text { Methylamylketone, Methylsalicylate-responsible for odour of clove }\end{array}$ \\
\hline Leaf oil & $\begin{array}{l}\text { Essential oil - 3.0-4.8\% } \\
\text { At different stages of leaf growth euginol content increases from } 38.3 \text { to } 95.2 \% \\
\text { WhereasEuginyl acetate decreases from } 51.2 \text { to } 1.5 \% \text { and caryophyllene from } 6.3 \text { to } \\
\end{array}$ \\
\hline $\begin{array}{l}\text { Clove stem } \\
\text { oil }\end{array}$ & $\begin{array}{l}\text { Essential oil- 6\% } \\
\text { Euginol- 80.2\% } \\
\text { Beta caryophyllene- } 6.6 \%\end{array}$ \\
\hline Fruit oil & $\begin{array}{l}\text { Essential oil- 2\% } \\
\text { Euginol - 50-55\% }\end{array}$ \\
\hline
\end{tabular}

\subsection{Nonvolatile constituents-}

\begin{tabular}{|l|l|}
\hline Constituents & Percentage \\
\hline Tannins & Tannin 10-13\% isolated from clove \\
& Eugenin, ellagitannin isolated from clove \\
& Euginolglucosidegallate, Chromone C-glycoside isolated from leaves \\
\hline
\end{tabular}


${ }^{1}$ Dr. Salve Nilesh, International Journal of Ayurvedic \& Herbal Medicine 7(4) July.-Aug.2017 (2685-2692)

\begin{tabular}{|l|l|}
\hline Triterpenes & Syzyginin A, syzyginin B islated from leaves \\
\hline Sterols & $\begin{array}{l}\text { Clove contains Triterpines and oleanolic acid 2\% } \\
\text { Maslinic acid isolated from clove buds } \\
\text { 2- alpha hydroxyoleanolic acid isolated from clove }\end{array}$ \\
\hline Flavonoids & Sitosterol, stigmasterol and campesterol \\
\hline & $\begin{array}{l}\text { C-glucoside, isobiflorin isolated from ethinolic extract of cloves } \\
\text { Apigenin isolated from ethanol extract of the seeds }\end{array}$ \\
\hline
\end{tabular}

\subsection{Pharmacological uses-}

1. Anti-oxidant activity-Clove has the highest anti-oxidant property. It has inhibitory effect against hydroxyl radicals and it also act as iron chelator. The anti-oxidant activity ofeuginol and euginolacetate were comparable with alpha Tocopherol like natural anti-oxidants ${ }^{[7]}$.

2. Anti-microbial activity- Clove posses great antiseptic property. Clove oil is effective against Styphylococcus species, Aspergillusniger, Klebsiella pneumonia, Pseudomonas aeruginosa, Clostridium perfringens, E. Coli and Candida albicans ${ }^{[8]}$. Euginol is effective against tuberculosis.

3. Anti-viral activity -Eugininalso shows antiviral activity against herpes virus at a concentration of 10 $\mathrm{mcg} / \mathrm{ml}^{[9]}$

4. Anti-inflamatory-Euginol functions as Anti-inflammatory agent. Clove contains large number of flavonoids such as Beta caryophyllene, Rhamnetin which initiate clove's anti-inflammatory and antioxidant properties $^{[10]}$

5. Antipyretic -Euginol, main component of clove oil reduces fever through a central action similar to that of acetaminophen. ${ }^{[11]}$

6. Anti-carcinogenic- It is found that, aqueous infusion of clove reduces lung carc-inogenesis strain in mice. it significantly reduces number of proliferating cells. ${ }^{[12]}$

7. Anti-diabetic- Clove regulates the expression of same genes in similar manner to that of insulin. ${ }^{[13]}$

8. Antiplatelet- It was found that both euginol and euginol acetate are potent in inhibiting platelet aggregation. ${ }^{[14]}$

9. Anti-stress- Clove extract found to be usefull in releving anoxic stress induced convulsions in mice. ${ }^{[15]}$

10. Aphrodisiac-Ethinolic extract of clove found to be effective in increasing sexual sexual activity of normal male rats. ${ }^{[16]}$

11. Mosquito repellent- Clove oil is found to be potent mosquito repellent ${ }^{[17]}$

12. Hepato-protective-Ethinolic extract of clove is found to be hepatoprotective in paracetamol induced liver injury. ${ }^{[18]}$

13. Cytotoxic activity- Clove oil has cytotoxic property towards human fibroblastsand endothelial cells. ${ }^{[19]}$

14. Fungicidal activity-It has been seen that euginol has anti candidial effect in oral candidiasis ${ }^{\text {[20] }}$

15. Bactericidal activity-Euginol has bactericidal effect against both positive and negative bacteria like streptococcus pyogenes,proteus vulgaris, Escherichia coli by disrupting their outer membrane ${ }^{[21]}$

16. Tooth ache-Euginol has analgesic effect in dental caries. Clove oil cotton plugs is been used in dental carries traditionally ${ }^{[22]}$ 
17. Anti-ulcer activity- Clove oil and euginol are capable of significantly enhancing mucus production therefore they found to be gastroprotective in function. In indomethacin ethanol induced ulcer euginol displays anti-ulcer activity. ${ }^{[23]}$

18. Reducing high fat diet induced obesity-Euginol found to effective in downregulation of adipogenic and lipogenic gene.[24]

19. Anti-carcinogenic in cervical cancer-Euginol in clove found to be anti-carcinogenic in breast cancer cells. $^{[25]}$

20. Stress- Clove oil is excellent stress reliver. Having stimulating effect on mind and it removes mental exhaustion and fatigue. It is also helpful in patient suffering from insominia. ${ }^{[26]}$

21. Muscle cramps and headache- Flavonoids present in clove oil has anti-inflammatory effect in general therefore clove oil is used for muscle cramps and headache. ${ }^{[27}$

\section{Discussion-}

This article basically focus on samhitagranthas reference of lavangaand its therapeutic uses describe in nighantugranthas. Along with that it also focuses on chemical constituents of clove oil and their pharmaceutical actions on human body. Clove has many important systemic effects, such as antiinflammatory actions, anti-pyretic actions, anti-carcinogenic actions, aphrodiasic action, stress releasing actions. With that it also has aampachaka, krumighna, sheershoolnashak, kaphachedana action due to its unique rasa panchak. It is very important to have some clinical trials on postulated pharmaceutical actions for further studies. So that it will help us to confirm its usefulness in treating patients

\section{Conclusion -}

Lavang being a major and most widely spice used in indiansub-continent. It possesseuginol like chemical constituents with many flavonoids which are having large effects on physiology of normal human being. Its tiktakatu rasa makes it best aampachak in various disorders. It acts as vaatshamak due to its sheet veerya. With its krumighnaprabahava it becomes more usefull in orodental disorder. And due to its aromatic flavonoids it act as mukhavaishadyakar. Euginol and euginol acetate has great fibroclastic activity on mucosal membrane. Clove is usefull as anti canrcinogenic agent in lung as well as in cervical cancers. So it is very important for us to have sound knowledge of its active principles and their actions. This article concludes that the herb which is described in our nighantugrantha as lavangahas great pharmaceutical applications. And it requires further clinical evaluation of the same.

\section{References-}

1. AacharyaPriyavat Sharma, DravyagunaVidnyan Volume2,Varanasi ChaukhambaBharti Academy, 2005 p- 246

2. Parle Milind And KhannaDeepa, Clove A Champion Spice. IJRAPvolume 2 issue 1,January 232011 , ISSN 2229-3566

3. AacharyaPriyavat Sharma, DravyagunaVidnyan Volume 2,Varanasi ChaukhambaBharti Academy, 2005 p- 247

4. AacharyaPriyavat Sharma, DravyagunaVidnyan Volume 2,Varanasi ChaukhambaBharti Academy, 2005 p- 248

5. ShreeBapalalVaidya, NighantuAdarsha Volume 1, Varanasi ChaukhambaBharti Academy,2002 p-590

6. Parle Milind And KhannaDeepa, Clove A Champion Spice. IJRAPvolume 2 issue 1,January 232011 , ISSN 2229-3566 
7. Gulcin I, Sat IG, Beydemir S, Elmastas M, Kufrevioglu OI. Comparison of antioxidant activityof clove (EugeniacaryophyllataThunb) buds and lavender (LavandulastoechasL.). Food Chemistry. 2004; 87: 393-400.

8. Briozzo J, Nunez L, Chirife J, Herszage L, D'AquinoM.Antimicrobial activity of clove oil dispersed in a concentrated sugar solution. J. Appl. Bacteriol. 1989; 66(1):69-75.

9. Chaieb K, Hajlaoui H, Zmantar T Kahla-Nakbi, A.B., Rouabhia, M., Mahdouani, K. and Bakhrouf, A. The chemical compositionand biological activity of essential oil, Eugenia Caryophyllata (Syzygiumaromaticum L. Myrtaceae): a short review Phytotherapy Research. 2007; 21(6): 501-506

10. Ghelardini C, Galeotti N, Di CesareMannelli L, Mazzanti G, Bartolini A. Local anaesthetic activity of $\beta$ -caryophyllene 11. Farmaco. 2001; 56: 387-389.

11. Feng J, Lipton JM. Eugenol: Antipyretic activity in rabbits. Neuropharmacology.1987; 26: 1775-1778.

12. Banerjee S, Das, S. Anticarcinogenic effects of an aqueous infusion of cloves on skin carcinogenesis. Asian Pac J. Cancer Prev. 2005; 6(3): 304-308.

13. Prasad RC, Herzog B, Boone B, Sims L, Waltner-Law L. An extract of Syzygiumaromaticum represses genes encoding hepatic gluconeogenic enzymes. J Ethnopharmacol. 2005; 96(1-2):295-301.

14. Srivastva KC. Antiplatelet principles from a food spice clove (Syzygiumaromaticum L). Prostaglandins LeukotEssent Fatty Acids. 1993; 48(5):363-72.

15. Singh AK, Dhamanigi SS, Asad M. Anti-stress activity of hydro-alcoholic extract of Eugenia caryophyllus buds (clove). Indian J. Pharmacol. 2009; 41:28-31

16. Tajuddin, Ahmed S, Latif A, Qasmi IA. Effect of $50 \%$ ethanolic extract of Syzygiumaromaticum (L.) Merr. \& Perry. Clove on sexual behaviour of normal male rats. BMC Complement Altern. Med. 2004; 4: 17.

17. Trongtokit Y, Rongsriyam Y, Komalamisra N, Apiwathnasorn C. Comparative repellency of 38 essential oils against mosquito bites. Phytotherapy Research. 2005; 19(4): 303-309

18. Sallie R, Tredger JM, William R. Drugs and the liver. Biopharmaceutics and drug disposition. 1991; 12: 251-259

19. BochraKouidhi, TarekZmantar, AminaBakhrouf. Anticarcinogenic and cytotoxic activity of clove essential oil (Eugenia caryophyllata) against a large number of oral pathogens. Annals of Microbiology. 2010;07: 599-604

20. Pinto E, Valer-Silva L, Cavaleiro C, Salgueiro E. Antifungal activity of clove essential oil from Syzygiumaromaticum on candida aspergillus and dermatophyte species. 2009; 58:1454-1462.

21. Briozzo J, Nunez L, Chirife J, Herszage L, D'AquinoM.Antimicrobial activity of clove oil dispersed in a concentrated sugar solution. J. Appl. Bacteriol. 1989; 66(1):69-75.

22. Ghelardini C, Galeotti N, Di CesareMannelli L, Mazzanti G, Bartolini A. Local anaesthetic activity of $\beta$ -caryophyllene 11. Farmaco. 2001; 56: 387-389.

23. Damiao P Desousa, fransisco de A O, Luciana N A,Elida B V. Anti ulcer Activity Of Essential Oil Constituents. International Journals of Molecular Sciences. 2014;05: 5717-5747

24. Chang H J, Jiyun A. Tae-ll J, Tae Y. Syzygiumaromaticum ethanol extract reduces high-fat dietinduced obesity in mice through downregulation of adipogenic and lipogenic gene expression. Journal of Experimental And Therapeutic Medicine. 2012;06: 409-414

25. Arif H, Kruti B, Anita P, Musthaq A, Tahir R, Chhavi S.. Euginol enhances the chemotherapeutic potential of gemcitabine and induces anticarcinogenic and aaaanti inflammatory activity in human cervical cancer cells. Cancer biotherapy and radiopharmaceuticals. 2011;10: 519-527 
${ }^{1}$ Dr. Salve Nilesh, International Journal of Ayurvedic \& Herbal Medicine 7(4) July.-Aug.2017 (2685-2692)

26. Singh AK, Dhamanigi SS, Asad M. Anti-stress activity of hydro-alcoholic extract of Eugenia caryophyllus buds (clove). Indian J. Pharmacol. 2009; 41:28-31

27. Ghelardini C, Galeotti N, Di CesareMannelli L, Mazzanti G, Bartolini A. Local anaesthetic activity of $\beta$ -caryophyllene 11. Farmaco. 2001; 56: 387-389 